\title{
Perceived Benefits of Adopting Standard - Based Pricing Mechanism for Mechanical and Electrical Services Installations
}

Ganiyu Amuda Yusuf and Sarajul Fikri Mohamed, (Universiti Teknologi Malaysia, Malaysia)

\begin{abstract}
Cost is an important measure of project success and clients will expect a reliable forecast at the early stage of construction projects to inform their business decision. This study was undertaken to investigate the current practices in managing cost of mechanical and electrical (M\&E) services in buildings. The perceptions of practitioners on the benefits of adopting Standard Based Pricing Mechanism for M\&E services as used for building fabrics and finishes was ascertained. The methodology adopted for the study was semi - structure interview and questionnaire survey. Inferential statistics technique was used to analyse the data collected. The results revealed that, M\&E services tender documents are often based on lump sum contract. Practitioners are of the opinion that the adoption of Standard - Based Pricing Mechanism (SBPM) could enhance the quality of M\&E services price forecasts; ensure active post contract cost monitoring and control; encourage collaborative working relationship; enhance efficient whole life cycle cost management; improve risk management and facilitate an efficient tendering process. The study suggested the development of local Standard Method of Measurement for M\&E services and proposed strategies to facilitate the adoption of SBPM as basis for forecasting contract price of mechanical and electrical services in buildings.
\end{abstract}

Keywords: Building fabrics, Forecast, Mechanical and Electrical services, Standard Method of Measurement, Standard-Based Pricing Mechanism

\section{Introduction}

The measurement of project success is subjective, but there seems to be a general agreement among researchers that a project is deemed successful if it meets clients' value criteria of time, cost and quality. Therefore, the principal activity of quantity surveyors at the early stage of construction projects is to establish the probable cost of such project and advice the client on cost - quality criteria (Bowen \& Edwards, 1996). However, the price determined at this early stage of construction projects forms the basis of the contract sum and is the amount established for the project which is not expected to be exceeded (Flanagan \& Tate, 1997). Therefore, the forecast should incorporate both foreseen and unforeseen costs needed for the achievement of clients' value criteria, (Flanagan \& Tate, 1997; Ling \& Boo, 2001). The value of the cost advice given by the quantity surveyor at this stage is the reliability of the cost estimates (Swaffield \& Pasquire, Improving Early Cost Advice for Mechanical and Electrical Services RICS Foundation Research Papers; 3 No.15, 2000), as this will provide real opportunities to add value to clients' business decisions and, the client will expect nothing but a reliable assessment of anticipated project value which will aid strategic decision making (Fortune \& Cox, 2005).

Effective cost management of M\&E services in buildings is highly desirable by industry stakeholders because of its significance and increasing complexity in modern buildings, which have tremendously impacted its relative cost to the total cost of building projects (Davis Langdon, 2010). However, cost advice on this element of buildings has historically been neglected by quantity surveyors because it was regarded as a specialist element, therefore, 
quantity surveyors only manage cost of building fabrics and finishes while engineers manage cost of M\&E services (McCaffrey, 2011). There has been increasing demand for specialist quantity surveyors to take charge of the cost management of M\&E services as a result of its increasing complexity and cost sensitivity (Rawlison, Nugent, \& Dedman, 2007). Industry stakeholders in the Malaysian Construction Industry have expressed concern on the cost management of M\&E services as practitioners often used the traditional approach and there is no uniformity in the methods adopted in preparing BoQ for building services (CIDB, 2009; Amuda Yusuf, Mohamed, \& Remeli, 2013a). This approach has been observed to be unsatisfactory and can lead to an unbalanced contract, as the BoQ may not be comprehensive enough so that the contractor must re-check for any omitted items, requiring more time and resources to carry out detail measurement (Flanagan \& Tate, 1997; Molloy, 2007; Potts K. , 2008).

It is established that there has been no empirically based work reported that considered the adoption of detail rules of SMM for forecasting price of M\&E services in the context of Malaysian Construction Industry. Therefore, this study is set out to investigate current budget estimating practices and determine the potential benefits of adopting the rules of SMM in forecasting M\&E services contract price. The study is divided into six sections with the introduction, followed by review of relevant literature on traditional building price forecasting process and the problems associated with M\&E services price estimating as well as the importance of SBPM. The method adopted for this research is described in section three while section four is data analysis and discussion of results. Sections five and six comprises of strategies to encourage practitioners to adopt SBPM for M\&E services and conclusions respectively.

\section{Literature Review}

\section{Forecasting Contract Price of Building Fabrics, Finishes and M\&E Services}

Measurement is central to the financial management of construction projects and it involves the Quantity Surveyors in measuring different types of work as shown on the drawings produced by the architect or engineer (Oforeh E. , 2008). The quantities are prepared in line with the rules of accepted SMM and the tender document prepared is referred to as BoQ. The completed BoQ is normally forwarded along with other documents for the contractor to price (Hore, Kehoe, Macmullan., \& Penton, 1997). The bill items measure the quantity in suitable physical units, such as cubic meters, enumeration and linear meters in line with detailed rules of the Standard Method of Measurement in use in the locality. The completed BoQ is normally forwarded along with other documents for the contractors to price. This process is referred to as Standard-Based Pricing Mechanism (SBPM) in the context of this study. However, this approach is only adopted for building fabrics and finishes by quantity surveyors. While prime costs sums are allowed for specialist works because they are not designed by the architect such as lifts, heating systems, air-conditioning systems and electricity supply systems; whereas provisional sums are allowed for works which cannot be adequately defined and quantified at the time of preparing tender documents such as substructure (Murray, 1997). However, all works covered by prime cost sum and provisional sums are appropriately adjusted at post contract stage when more design information are available.

The resulting estimate from this exercise usually forms the basis for price indices, compiled and used as historical cost data for future projects of similar characteristics either by individual organizations (cost data bank) or regulatory bodies like the Building Cost Information Service (BCIS). However, except for plumbing work, all mechanical and electrical service items including comfort cooling, heating systems, lighting, electrical supply systems, lifts, and fire detection systems are not measured in the index because mechanical and electrical services

Amuda Yusuf, G and Mohamed, S F (2014) 'Perceived benefits of adopting standard - Based pricing mechanism for mechanical and electrical services installations', Australasian Journal of Construction Economics and Building, 14 (2) 104119 
are usually included as lump sums in BoQ. The lump sums allowed in the BoQs for M\&E services are often determined by consultants based on the gross floor area from previous building projects (Swaffield \& Pasquire, 1996) single purpose deterministic estimate (Mok, Tummala, \& Leung, 1997) statistical and historical cost data (Nanayakkahara \& Fitzsimmons, 1999), building forms and functions (Swaffield \& Pasquire, Examination of Relationships Between Building Forms and Function and the cost of Mechanical and Electrical Services., 1999). The resultant estimates and cost plans used were not often based on projects with M\&E services of similar performance and aesthetic standards, as this information may not be identifiable from historic information (Swaffield \& Pasquire, Improving Early Cost Advice for Mechanical and Electrical Services RICS Foundation Research Papers; 3 No.15, 2000). The problems with this method of forecasting cost of M\&E services are well researched. Swaffield \& Pasquire (1996) examined the method used for the production of budget estimate for M\&E services by assessing the ease of use and appropriateness of historic cost data for engineering services. They found that the current method of budget estimating for building structure and fabric is not appropriate for M\&E services and there is need for a better understanding of the factors that affect the cost of engineering services.

Similarly, Mok et.al (1997) studied early-price estimation practices in Hong Kong and described the method used by building services engineers as single-figure deterministic estimate. They go on to state that the approach is illogical, cost ineffective and reactionary in nature and therefore inadequate for M\&E services project. Mok et.al (1997) proposed risk management processes as a logical and consistent approach of identifying and making appropriate allowances for risk factors in M\&E services cost estimation process. However, the study did not provide information about specific practices and how the process could be applied to effectively manage cost of M\&E services in building projects. According to James (Fortune \& Lees, 1999), single price rate approximate estimating could only be applied to determine the early price of only the building fabrics and finishes, they are not suitable for site works, special foundations and building services. He further stated that, the cost of building services are rarely constant between one project and another and is therefore a matter which requires separate attention when preparing budget estimate.

In a seminal work by Nanayakkahara \& Fitzsimmons (1999), they developed cost benchmark for buildings services in United Kingdom and examined some of the methods used in forecasting contract price of M\&E services and stated that the historical and statistical cost information generally used for M\&E services cost estimate lacks quality and consistency as costs are normally averages for similar installations but derived from projects with different attributes; the cost information available from tenders is generally related to the type of product rather than its quality and effectiveness of the management process responsible for developing it; published cost information does not normally identify the costs of project organization and administration, the design process and project management and their impact on construction cost and therefore not suitable for predicting cost of M\&E services.

McCaffrey, (2011)outlines the role of the mechanical and electrical services quantity surveyors and observed that, the traditional practices where quantity surveyors are only responsible for the building structure and finishes and the consulting M\&E engineers control cost of M\&E services failed because M\&E costs fall through the gap and are not properly managed. It has been observed that the traditional practices by quantity surveyors were partly because there was an interface problem between the knowledge base and skill of quantity surveyors and the technologies associated with M\&E services (Swaffield \& Pasquire, Improving Early Cost Advice for Mechanical and Electrical Services RICS Foundation Research Papers; 3 No.15, 2000).

Amuda Yusuf, G and Mohamed, S F (2014) 'Perceived benefits of adopting standard - Based pricing mechanism for mechanical and electrical services installations', Australasian Journal of Construction Economics and Building, 14 (2) 104119 
Furthermore, Swaffield \& Pasquire (2000) proposed a method of analysing the quality of M\&E services in a way that could be understood by quantity surveyors. They suggested that if the method is adopted it would bridge the gap between quantity surveyors' knowledge and M\&E services technology, enable more detailed analysis of M\&E service costs, facilitate the collection of more appropriate historic cost information and enable quantity surveyors to make better use of M\&E services information. However, the method proposed by Swaffield \& Pasquire (2000) could not be applied to test its reliability because the tender documents collected and analyzed were prepared by specialist contractors and are not prepared based on a uniform method hence they could not reconcile the information contained in the various documents for the purpose of further analysis.

\section{Standard - Based Pricing Mechanism (SBPM)}

The major cost decisions on construction project are made at the early stages of design development when little information is available for computing estimates. However, more information are made available as design progresses which could lead to more reliable estimate, but the highly important decision made based on unreliable estimates are often difficult to reverse (Skitmore \& Thomas $\mathrm{Ng}$, 2003). Fortune (Fortune \& Lees, 1999) stated that enhancing the quality of building project price forecasts will increase the level of clients' satisfaction with the services provided by design team professionals. Fortune (Fortune \& Cox, 2005) pointed out that practitioners often evaluated forecasting models on single criterion of the perceived level of model output accuracy. They comment that accuracy cannot be considered as the sole criterion of forecasting model selection process as it was not necessarily only the product of the model that needed to be evaluated. According to Fortune (Fortune \& Lees, 1999), the quality of building price forecast is also affected by both the technical formulation of the price forecast itself and the human processes involved with the interpretation and transmission of the price forecast to clients.

Therefore, to improve the quality of price forecast advice given by cost consultants, it is essential to consider enhancement of the process itself. In order to improve the process of producing building project price forecast given at the early stages of design development, (Skitmore M. , 1991) suggested the developing of entirely new estimating techniques or using detailed estimating techniques (e.g. BoQ) in the earlier design stages. Quantity based methods of pre -contract price determination may have to serve until better methods are available, but they should be used with all possible skill and judgment. Although, quantity based costing method may not be suitable for design advise but the method remain the most reliable tools available because it is more suitable for forecasting the cost of a whole design. Olatunji et.al (2010) argued that, until electronically generated design drawings can create consistent information suitable to be priced by contractors, the skill of quantification measurement from drawings will remain important. In fact, the measurement of BoQ for $M \& E$ services is increasing due to the rising and significant proportion of building cost that can be represented by these services.

\section{Research Methodology}

The study started with a review of relevant literature which includes materials from textbooks, journals, magazines, government and government agencies reports, conference proceedings and web trawl. The objective of the literature review was to develop an overall framework for the research study and to prepare for the questionnaire survey. This was followed by a study of secondary data and interview of practitioners in the industry.

Amuda Yusuf, G and Mohamed, S F (2014) 'Perceived benefits of adopting standard - Based pricing mechanism for mechanical and electrical services installations', Australasian Journal of Construction Economics and Building, 14 (2) 104- 
The study was conducted in two stages. The first stage was conducted through analysis of secondary data. Data were obtained from past bills of quantities of M\&E services projects in Southern Peninsular Malaysia and semi structured interview of practitioners involved on the project was conducted (this part of the study is not reported in this paper). The second stage of the study was conducted using the quantitative method through a questionnaire survey in order to get information from a larger population, as the goal of built environment research is the development of theory through explanatory rather than creation of generalizations (Fellows \& Liu, 2008). Therefore, a qualitative method could be integrated with a quantitative approach to achieve results on the issues being examined, the people to be studied, and the changes that are needed (Amaratunga, Baldry, Sarshar, \& Newton, 2002).

It is considered that, qualitative approach is appropriate to investigate the current method of measuring M\&E services by examining practitioners in the industry and review of related contract documents through document review and semi-structured interview. Quantitative strategy assisted in getting more information from industry wide practitioners about their views, on the current practices and the potentials of adopting SBPM. This was achieved through structured questionnaire survey. In addition, qualitative methods were adopted to give general explanations of the survey results and their relationships with the research aims and objectives. This is in line with the claim that mixed method approach can compensate for the strength and weaknesses inherent in each of the methods (Amaratunga, Baldry, Sarshar, \& Newton, 2002).

\section{Questionnaire Survey}

The survey questionnaire was designed by incorporating the benefits of SBPM as identified from literature. A total of 14 perceived benefits of SBPM identified in literature formed the basis of the survey. A pilot study was conducted among the industry experts and this assisted in enhancing the quality and appropriateness of questions posed. The targeted practitioners are Architects, Quantity surveyors, Electrical and Mechanical engineers and Structural engineers working in clients, consultancy, contracting and multidisciplinary types of organizations. A total of 375 questionnaires were distributed by means of both postal and e-mail. Follow -up communication through email, telephone and visits to the respondents' offices lead to the return of 167 questionnaires which represents about 45 per cent of questionnaire sent out. 4 of the questions were not properly filled therefore could not be analysed. Therefore analysis of result was based on 163 valid questionnaire returned. Respondent were requested to rate their responses on a 5 points Likert scale from $1=$ strongly disagree, 2 = disagree, $3=$ moderately agree, 4 = agree and 5 = strongly agree.

\section{Data Analysis and Discussions}

\section{Profile of Respondent}

All respondents are well experienced and are professionals in the construction industry. Only 9 per cent of the respondents have experience ranging between 6 to 10 years, the remaining 91 per cent have experience between 11 to 20 years and above. Therefore, their opinions to survey questions are considered reliable and appropriate for this study.

\section{Documents used for M\&E Services Tender}

Respondents were requested to select from a list of three options, the type of documents used to invite bid for M\&E services contract. Only 21 per cent indicated the use of detail bill of quantities, 66 per cent selected Lump sum and the remaining 13 per cent indicated that drawings and schedule of rates are used. This result showed that M\&E services tenders are often invited based on lump sum tender documents. The result is in line with the findings in the secondary data reviewed during the first phase of this research. However, it is worth mentioning

Amuda Yusuf, G and Mohamed, S F (2014) 'Perceived benefits of adopting standard - Based pricing mechanism for mechanical and electrical services installations', Australasian Journal of Construction Economics and Building, 14 (2) 104119 
that, what is referred to as detail $B o Q$ is an equivalent of approximate quantities used at the preliminary stage of the building projects where three to four items are combined and described together without reference to any standard documents. For example, underground cables were only described, without reference to excavation, nature of ground to be excavated, the kind of backfilling materials and specification of underground cable protection. Another example is where cables are to be drawn in trunking and cables trays, only cables are usually properly specified. The type of materials for cable trays and trunking, necessary support required, receiving backgrounds and accessories are often neglected for contractors to decide, moreover, these items could be made from materials of different quality and prices (e.g cast iron, galvanized steel etc). In addition, preamble section of the BoQ often contain provisions such as

the sub - contractor shall provide all materials fittings or perform any work necessary for the proper installation of the work ... even though such materials or work may not be explicitly mentioned in the specification or shown in the drawings...

According to Rawlinson \& Dedman (2010) this type of provisions will safeguard the employer from being held accountable to the contractor for any inaccuracies in tender documents. However, Molloy (2007) opined that such provisions are "short - sighted in the extreme and serve only to destroy the primary functions of BoQ". Molloy further argued that if the engineer does not know for certain what is allowed for in each rate, how can he use those rates for the valuation of variations? Similarly, if one of the "deemed included" item is omitted how can such omission be valued?

\section{Estimating Method used for M\&E Services}

The most popular estimating method used during the design phase was found to be superficial area method (72 per cent), this is followed by unit method (10 per cent) and approximates quantities (7), the least used method is standard - based detail measurement (5 per cent) followed by elemental method (6 per cent). This results shows that detail measurement in line with standard method of measurement were not adopted in preparing M\&E services precontract budget estimate. During the follow up interview, some of the respondents comment that differences in the initial contract sum and final account figure is the most difficult problem on M\&E services contract, while some stated that 'we always have problems with consultants in measurement of actual cable length used on site'. Another problem is with main contractor and subcontractor relationships: "sometimes "main con" will ask us to make good all works disturbed during installation of cables and conduit pipes'

On the reasons why details rules of SMM were not adopted for M\&E services BoQ Quantity Surveyors said that they only allow prime cost sums for M\&E services work and detailed breakdowns are done by M\&E services engineers or contractors based on performance specifications. They also stated that they don't have good knowledge of M\&E services; therefore it is difficult for them to provide standard - based quantity as done for building fabrics and finishes. A large proportion of quantity surveyors argued that, M\&E services design are often not ready for quantification at tender stage and design consultants mostly give out performance specifications to contractors for tendering purposes, therefore, contractors always use their own method to arrive at tender price. Some of the consultant services engineers stated that they are not aware of any SMM, while majority are of the opinion that they don't have knowledge of how to use SMM that only quantity surveyors were trained on how to use SMM.

\section{Practitioners Perceptions of the Adoption of Standard-Based Pricing Mechanism}

On the practitioners' perception about the proposition that 'adoption of SBPM for M\&E services could lead to a better cost management of M \& E services projects in the industry. Respondents

Amuda Yusuf, G and Mohamed, S F (2014) 'Perceived benefits of adopting standard - Based pricing mechanism for mechanical and electrical services installations', Australasian Journal of Construction Economics and Building, 14 (2) 104- 
were requested to indicate their level of agreement on Likert scale 1 to 5 , where $1=$ strongly disagree and 5 is strongly agree. The result shows that adoption of SBPM could lead to a better cost management of M\&E services contract. As can be seen on Table 1, 77 per cent of the practitioners agreed, 19 per cent disagreed while 4 per cent were undecided. A cursory look at the table also revealed that the large percentage of practitioners that disagreed are mechanical and electrical services engineers as 30 per cent mechanical and 32 per cent electrical engineers that responded disagreed that SBPM would provide good basis for managing cost of M\&E services in buildings.

\begin{tabular}{|l|c|c|c|c|c|c|}
\hline \multicolumn{1}{|c|}{ Discipline } & $\begin{array}{c}\text { Strongly } \\
\text { disagree }\end{array}$ & Disagree & $\begin{array}{c}\text { Moderately } \\
\text { agree }\end{array}$ & $\begin{array}{c}\text { Agree } \\
15 \text { per } \\
\text { cent }\end{array}$ & $\begin{array}{c}\text { Strongly } \\
\text { agree }\end{array}$ & $\begin{array}{c}\text { Total } \\
\text { responses }\end{array}$ \\
\hline $\begin{array}{l}\text { Quantity } \\
\text { Surveyors }\end{array}$ & 5 per cent & 5 per cent & 0 per cent & 100 per cent \\
\hline $\begin{array}{l}\text { Mechanical } \\
\text { Engineers }\end{array}$ & $\begin{array}{c}15 \text { per } \\
\text { cent }\end{array}$ & $\begin{array}{c}15 \text { per } \\
\text { cent }\end{array}$ & 0 per cent & $\begin{array}{c}46 \mathrm{per} \\
\text { cent }\end{array}$ & 23 per cent & 100 per cent \\
\hline $\begin{array}{l}\text { Electrical } \\
\text { Engineers }\end{array}$ & $\begin{array}{c}14 \text { per } \\
\text { cent }\end{array}$ & $\begin{array}{c}16 \text { per } \\
\text { cent }\end{array}$ & 2 per cent & $\begin{array}{c}18 \text { per } \\
\text { cent }\end{array}$ & 50 per cent & 100 per cent \\
\hline Civil Engineers & $\begin{array}{c}15 \text { per } \\
\text { cent }\end{array}$ & $\begin{array}{c}6 \text { per cent } \\
27 \text { per } \\
\text { cent }\end{array}$ & 30 per cent & 50 per cent & 100 per cent \\
\hline Architects & 4 per cent & $\begin{array}{c}12 \text { per } \\
\text { cent }\end{array}$ & 4 per cent & $\begin{array}{c}27 \text { per } \\
\text { cent }\end{array}$ & 54 per cent & 100 per cent \\
\hline Others & 0 per cent & 0 per cent & 0 per cent & $\begin{array}{c}50 \text { per } \\
\text { cent }\end{array}$ & 50 per cent & 100 per cent \\
\hline
\end{tabular}

Table 1 Practitioners' Perception on the Adoption of SBPM for M\&E Services

\section{Benefits of Adopting SBPM for Mechanical and Electrical Services}

The objective of this section is to determine the level of importance attached to each of the benefits. Therefore, respondents were requested to rate their level of agreement as indicated in the previous sections. This standpoint was verified at a significance level of 5 per cent and 162 degree of freedom $(n=163-1)$ using a one-way t-test statistics, the critical rating was set at 3 because on the rating scale adopted 3 are neutral. Therefore, SBPM benefits-rating below 3 are not significant (De Silva, Dulaimi, Ling, \& Ofori, 2004)

The result of the t-test statistics is shown on Table 2, the mean score of each benefit of SBPM from the perspective of the practitioners were calculated and ranked according to the magnitude of their mean score. The five most important factors in order of importance includes SBPM minimize measurement related disputes; provide good basis for valuing variations; provide good basis for assessing interim valuation; reduces tendency of misinterpretation of specifications and, improve accuracy of initial budget estimate. However on the tendency of SBPM reducing the time and cost of tender, with a mean score of 2.98, and p-value $>0.05$ at 162 degree of freedom. It is therefore reasonable to state that, from the perspective of the practitioners, this factor is insignificant and does not constitute benefit of SBPM. It is important to state that the remaining 13 benefits of SBPM are statistically significant $(p<0.05)$.

\section{Statistical Validity and Results}

The correlation matrix shows how each of the 14 items is associated with each of the 13 others and the SBPM benefits provided a 'determinant' value of 0.099 . The underline assumption is that, the determinant should be more than 0.00001 and the value here is 0.099 from which it can be assumed that the matrix does not suffer from collinearity. Moreover, the Kaiser -Meyer Olkin (KMO) and Bartlett's test results measures the sampling adequacy which should be greater than 0.5 for a satisfactory factor analysis to continue. The KMO statistics ranges from 0

Amuda Yusuf, G and Mohamed, S F (2014) 'Perceived benefits of adopting standard - Based pricing mechanism for mechanical and electrical services installations', Australasian Journal of Construction Economics and Building, 14 (2) 104119 
to 1 . A value of 0 implies that the sum of partial correlations is large relative to the sum of correlations, therefore factor analysis will be inappropriate, on the other hand, a value close to 1 implies that patterns of correlations are relatively compact and factor analysis would yield distinct and reliable individual factors (Gravetter \& Wallnau, 2007) The KMO value is 0.712 which indicate a good degree of common variance and is above the acceptable threshold of 0.5 , similarly, the Bartlett's test of sphericity is significant at 459.92 compared with associated significance level , and the associated probability is less than 0.05 ( $p$-value $=0.000$ ), meaning that the correlation matrix is not an identity matrix. The results of the analysis revealed that the coefficients of correlation between pairs of the variables were small when the effects of other variables were eliminated (Gravetter \& Wallnau, 2007). Therefore, the data collected were adequate for factor analysis and appropriate for the factors extraction.

\begin{tabular}{|c|c|c|c|c|c|}
\hline Benefits SBPM & t-value & Mean & $\begin{array}{l}\text { P- } \\
\text { value }\end{array}$ & $\begin{array}{l}\text { Std. } \\
\text { Deviation }\end{array}$ & Rank \\
\hline Minimize measurement related disputes & 24.355 & 4.5460 & 0.000 & .81044 & 1 \\
\hline Provide good basis for valuing variations & 20.402 & 4.4785 & 0.000 & .92521 & 2 \\
\hline provide good basis for assessing interim valuation & 17.652 & 4.4049 & 0.000 & 1.01615 & 3 \\
\hline $\begin{array}{l}\text { Reduces tendency of misinterpretation of } \\
\text { specifications }\end{array}$ & 17.985 & 4.3742 & 0.000 & .97554 & 4 \\
\hline Improve accuracy of initial budget estimate & 15.769 & 4.3129 & 0.000 & 1.06297 & 5 \\
\hline $\begin{array}{l}\text { Avoid the need for contractors to measure M\&E } \\
\text { work }\end{array}$ & 19.205 & 4.2761 & 0.000 & .84830 & 6 \\
\hline Provide reliable database for future cost planning & 14.936 & 4.2086 & 0.000 & 1.03312 & 7 \\
\hline $\begin{array}{l}\text { Assist contractors in ordering and preparing labor } \\
\text { schedule }\end{array}$ & 13.582 & 4.0859 & 0.000 & 1.02076 & 8 \\
\hline $\begin{array}{l}\text { coding system allow ease of automation of } \\
\text { estimating process }\end{array}$ & 10.016 & 3.9198 & 0.000 & 1.16884 & 9 \\
\hline Ensure reflection of local practices and procedure & 8.153 & 3.8160 & 0.000 & 1.27773 & 10 \\
\hline Ensure that design is completed prior to tender & 7.941 & 3.6503 & 0.000 & 1.04547 & 11 \\
\hline Enhance risk management & 5.136 & 3.5276 & 0.000 & 1.31145 & 12 \\
\hline Assist in asset management & 2.362 & 3.2331 & 0.000 & 1.25988 & 13 \\
\hline Reduce time and cost of tender & -.208 & 2.9816 & 0.836 & 1.13024 & 14 \\
\hline
\end{tabular}

Table 2 Practitioners Perception of the Benefits of SBPM

The main purpose of factor analysis is to statistically reduce the number of factors on which the variables under investigation have high loadings, so as to make the interpretation of the analysis easier (Proverbs, Holt, \& Olomolaiye, 1999). The extracted factors were subjected to principal component analysis and varimax with Kaiser Normalization rotation. The result shows that the 14 factors identified produced a six-factor solution along with their eigenvalues greater than 1. The cumulative percentage of variance explained accounted for 66.53 and the per cent of

Amuda Yusuf, G and Mohamed, S F (2014) 'Perceived benefits of adopting standard - Based pricing mechanism for mechanical and electrical services installations', Australasian Journal of Construction Economics and Building, 14 (2) 104119 
variance attributable to each factor are shown on Table 2. However, the loadings of the fourteen variables on six factors extracted were subjectively classified under six categories on Table 3. The criteria for group classification were that variables with a loading value higher than 0.50 in one component belong to that component (Awakul \& Ogunlana, 2002). The higher the absolute value of the loading, the more the factor contribute to the variable, the gap on the table represent loadings that are less than 0.5 because loadings less than 0.5 were suppressed. The first three grouped factors accounted for 14.024 per cent, 11.726 per cent and 11.411 per cent respectively. All the remaining factors after the sixth factor are not significant and were not reflected in the results.

Furthermore, Figure 1 is the scree plot graph of the Eigen values against the factor number. The loadings of the 14 factors were higher than 0.50. It is generally assumed that the higher the absolute value of the individual factor loading, the more a particular individual factor contributes to its group components (Proverbs, Holt, \& Olomolaiye, 1999). A cursory look at the figure shows that from the sixth factor, the successive factor is accounting for smaller and smaller amounts of the total variance. This is a further proof that six - factor group is sufficient for the components.

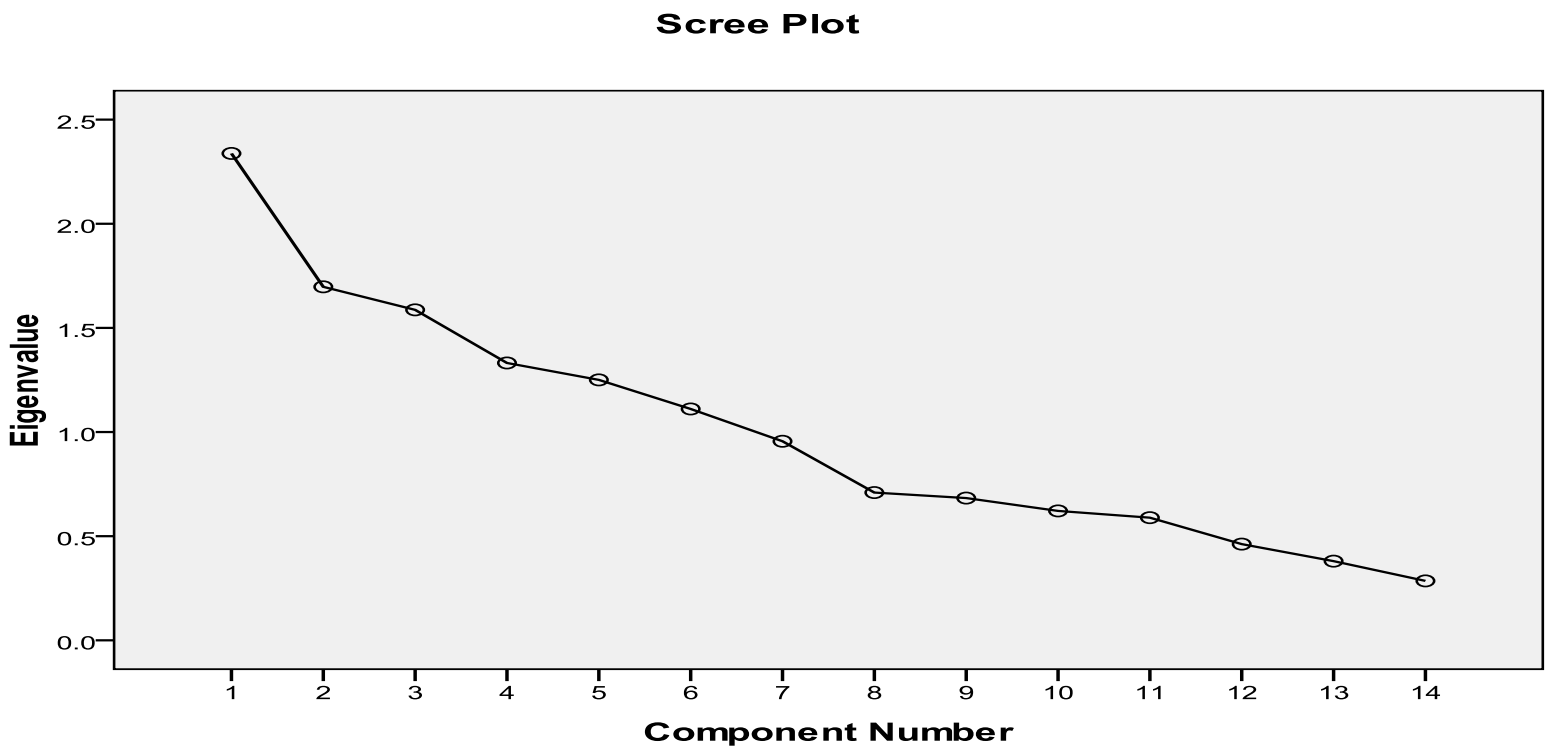

Figure 1 Scree Plot Graph of Eigen Values

\section{Discussion of Factor Analysis}

\section{Factor 1: SBPM Enhance quality and reliability of Price Forecast}

This factor account for 14.02 per cent of the variance and comprises of four benefits of SBPM; minimize measurement related disputes, ensure reflection of local practices and procedures, improve accuracy of initial budget estimate and reduces tendency of misinterpretation of specifications. The loading of these four benefits are 76 per cent, 65 per cent, 59 per cent and 56 per cent respectively. The correlation matrix showed significant statistical relationship between the four benefits. The association between the four benefits as shown in the correlation matrix (Table 3). All the four benefits in this group share common features which is their impact on the quality and reliability of early contract price estimate, and hence factor 1 was labelled enhance quality of price forecast.

Amuda Yusuf, G and Mohamed, S F (2014) 'Perceived benefits of adopting standard - Based pricing mechanism for mechanical and electrical services installations', Australasian Journal of Construction Economics and Building, 14 (2) 104- 
Standard-Based quantity provides a more sensitive and balanced description of the value of work in a contract. Therefore, all necessary works required for the installations of M\&E services components are properly quantified in line with the accepted SMM at the pre-contract stage for contractors to submit bids. The resulting document will serve as a basis upon which the entire work will be executed and paid for, therefore contractors would be able to determine the amount due upon execution of a particular section(s) of the work. This will reduce the tendency of measurement disputes. SBPM would also reduce the possibility of misinterpretation of specifications because; SMM usually reflects local practices, statutory requirements to be complied with, acceptable materials as well as quality of workmanship required. This is because the value attached to a particular item of work by tendering contractor is a function of information provided which serves as basis for determining the rate to be inserted against each item of work (Oforeh E. , 2008). However, if there are ambiguities in the description regarding the exact M\&E services components, the tendering contractors will price based on their understanding of the specification leading to disputes at the post-contract stage. On the other hand, a clearly defined components will lead to effective communication from the cost consultant to the tenderers resulting into a more accurate and reliable estimate.

\section{Factor 2: Ensure active post contract cost monitoring and control}

This factor account for 11.73 per cent of the variance and comprises of two benefits of SBPM. It provides good basis for assessing interim valuation and assist contractors in ordering and preparing labour schedule. The loading of these two factors are 74 per cent and 58 per cent respectively. Similarly, the correlation matrix in Table 3 shows that there is a strong association between the two benefits loaded under this factor. This benefit of SBPM was labelled 'ensure active post contract cost monitoring and control'. Each of these factors helps the project team and specifically the cost consultants and the contractor to be involved in active monitoring and control. SBPM facilitate the production of periodic interim valuation for payment to contractor, prepare earn value analysis, and assist in reporting the financial position of M\&E services project since all the cost significant items have been clearly identified and priced at pre contract stage of the building project. Similarly, it would serve as basis for developing reliable work breakdown structure (WBS) by the contractor. This WBS could assist the contractor in material ordering, preparation of labour schedule; cash flow forecast and cost value reconciliations as well as a reliable programme.

\section{Factor 3: Encourage collaborative working relationship}

Factor 3 comprises of SBPM ensure that design is completed prior to tender (71 per cent loading) and that the coding system would allow ease of automation of the price estimating process (70 per cent loading), and has been labelled 'encourage collaborative working relationship' and account for 11.4 per cent of the variance in the selection factors. The measurement process will provide a check against the original design because at the early stage of building projects SBPM relies on detail design information from design consultants to prepare price forecasts. When design information are not clearly presented, the quantity surveyors usually issue queries to design consultants for clarification of omitted and ambiguous design information thereby facilitating dialogue between the quantity surveyor and M\&E design consultants and ensure collaborative working relationships with other team members, leading to clearly defined clients requirements and reasonably completed design as well as a correctly described and accurately measured BoQ. In addition, it will also help in establishing relationship between the cost of M\&E services and the quality of its components. Similarly, the coding system in SMM facilitates automation of the taking-off process, and hence making feasible the application of information and communication technology like auto-quantity generation from auto-CAD and other computer applications. In addition, Building Information Modelling (BIM)

Amuda Yusuf, G and Mohamed, S F (2014) 'Perceived benefits of adopting standard - Based pricing mechanism for mechanical and electrical services installations', Australasian Journal of Construction Economics and Building, 14 (2) 104119 
measurement and its links with estimating require the need to filter BIM data so that they comply with the rules prescribed in relevant SMM (Olatunji, Sher, Gu, \& Ogunsemi, 2010).

\begin{tabular}{|c|c|c|c|c|}
\hline Variables & $\begin{array}{l}\text { Factor } \\
\text { loading }\end{array}$ & $\begin{array}{l}\text { Eigen } \\
\text { value }\end{array}$ & $\begin{array}{l}\text { Percentage } \\
\text { of variance } \\
\text { explained }\end{array}$ & $\begin{array}{c}\text { Cumulative } \\
\text { percentage } \\
\text { of variance } \\
\text { explained }\end{array}$ \\
\hline \multicolumn{5}{|l|}{ Factor 1: Enhance quality of Price Forecast } \\
\hline i. Minimize measurement related disputes & 0.763 & 2.338 & 14.024 & 14.024 \\
\hline $\begin{array}{l}\text { ii. Ensure reflection of local practices and } \\
\text { procedure }\end{array}$ & 0.653 & & & \\
\hline $\begin{array}{l}\text { iii. Improve accuracy of the initial budget } \\
\text { estimate }\end{array}$ & 0.588 & & & \\
\hline $\begin{array}{l}\text { iv. Reduces tendency of misinterpretation of } \\
\text { specifications }\end{array}$ & 0.562 & & & \\
\hline \multicolumn{5}{|c|}{ Factor 2: Ensure active post contract cost monitoring and control } \\
\hline $\begin{array}{l}\text { i. provide a good basis for assessing interim } \\
\text { valuation }\end{array}$ & 0.740 & 1.697 & 11.726 & 25.750 \\
\hline $\begin{array}{l}\text { ii. Assist contractors in ordering and preparing } \\
\text { labour schedule }\end{array}$ & 0.584 & & & \\
\hline \multicolumn{5}{|l|}{ Factor 3: Encourage collaborative working relationship } \\
\hline $\begin{array}{l}\text { i. Ensure that design is completed prior to } \\
\text { tender }\end{array}$ & 0.708 & 1.587 & 11.411 & 37.160 \\
\hline $\begin{array}{l}\text { ii. The coding system allow ease of } \\
\text { automation of estimating process }\end{array}$ & 0.700 & & & \\
\hline \multicolumn{5}{|c|}{ Factor 4: Enhance efficient whole life cycle management of completed projects } \\
\hline i. Assist in asset management & 0.842 & 1.332 & 10.369 & 47.530 \\
\hline \multicolumn{5}{|l|}{ Factor 5: Enhance risk and change order management } \\
\hline i. Provide good basis for valuing variations & 0.761 & 1.250 & 9.861 & 57.390 \\
\hline ii. Enhance risk management & 0.618 & & & \\
\hline $\begin{array}{l}\text { iii. Provide reliable database for future cost } \\
\text { planning }\end{array}$ & 0.560 & & & \\
\hline \multicolumn{5}{|l|}{ Factor 6: Facilitate efficient tendering process } \\
\hline i. Reduce time and cost of tender & 0.830 & 1.111 & 9.141 & 66.532 \\
\hline $\begin{array}{l}\text { ii. Avoid the need for contractors to measure } \\
\text { M\&E services work themselves }\end{array}$ & 0.536 & & & \\
\hline
\end{tabular}

Table 3 Principal factor extraction and Varimax Rotation of 14 Benefits of SBPM

Factor 4: Enhance efficient whole life cycle cost management

This factor consists of assist in asset management with a factor loading of 84 per cent and accounts for 10.4 per cent of the variance in the selection factors. M\&E services in buildings are becoming more complex and the capital cost of the various systems and components could be

Amuda Yusuf, G and Mohamed, S F (2014) 'Perceived benefits of adopting standard - Based pricing mechanism for mechanical and electrical services installations', Australasian Journal of Construction Economics and Building, 14 (2) 104- 
less than half of the whole life cycle cost. Therefore, the adequacy of information in the tender will ensure that the contractor quote for exact and durable materials and components which will impact maintenance cost. In addition, SBPM will assist in setting up a life cycle data bank on M\&E services components and equipment which will assist in projecting maintenance costs. This will ensure that sufficient information about the performance and aesthetic standard of M\&E services on completed projects are known, thus, making it possible to reliably predict equipment life span.

\section{Factor 5: Enhance risk and change order management}

This factor was labelled enhance risk and change order management, and it accounts for 9.9 per cent of the variance in the selection factors. This group comprises of SBPM and provides a good basis for valuing variations; enhance risk management and provide a reliable data base for future cost planning with loading factor values of 76 per cent, 62 per cent and 56 per cent respectively. The use of SBPM results in the pricing risk being retained by the client as far as quantities are concerned leading to more competitive prices being obtained as risk is more evenly distributed with the client taking a greater burden. In this case the contractors' risk is reduced to the tender price and not the extent of work. However, if the contractor is allow to measure the work, the risk for the extent of the work rests with the contractor and there is no assured consistency in the measurement process thereby increasing the likelihood of post contract variation.

\section{Factor 6: Facilitate efficient tendering process}

Factor 6 accounted for 9 per cent of the variance and comprises two factors; SBPM reduce time and cost of tender (83 per cent loading) and avoid the need for contractors to measure M\&E services work themselves (54 per cent loading). The aims of the tendering procedure are to assess the skills of the contractor; to translate to the contractor through the tender documentation all the project information, including the client's objectives, required to form the contract; and to obtain a competitive quote (RICS, 2000). The availability of standard-based quantity will increase the efficiency in obtaining competitive tenders from subcontractors on M\&E services, ensuring that estimators are able to price SMM bill more accurately than one which is not prepared to any particular method of measurement, and prices obtained from specialist subcontractors will be more accurate if SMM rules apply (Potts K. , 2004).

\section{Adoption of Standard-Based Pricing Mechanism}

To ensure successful adoption of Standard-Based Pricing Mechanism it is essential to consider the following:

\section{i. Education and Training of Professionals}

Total cost management of buildings should be the responsibility of quantity surveyors but they still do not have adequate knowledge of M\&E services technology, therefore, there is need for capacity building, for quantity surveyors to develop a better understanding of the technology of mechanical and electrical services so as to improve the quality of price advice given to clients.

\section{ii. Development of Standard Method of Measurement}

Development of a generally accepted Standard Method of Measurement for M\&E services that will reflect the local practices and procedures is essential to serve as a basis for predicting the probable cost of building services. In addition, relevant industry stakeholders should be identified and a strategy to manage them developed so as to agree on the best classification method for SMM for Mechanical and Electrical services.

Amuda Yusuf, G and Mohamed, S F (2014) 'Perceived benefits of adopting standard - Based pricing mechanism for mechanical and electrical services installations', Australasian Journal of Construction Economics and Building, 14 (2) 104- 
iii. Early involvement of design and specialist consultants and contractors

Early involvement of M\&E services design consultants is essential. Industry stakeholders should also be encouraged to develop strategy to involve major downstream supply chain at the inception of M\&E services project to reduce the risk of incomplete design information that could prevent the use of SBPM.

\section{iv. Application of Value Engineering}

Industry stakeholders should also consider the application of Value engineering at the early stage of M\&E services project. This would assist in equipment selection based on function and whole life cycle costs thereby ensuring that clients achieve absolute value for money. In addition, it will ensure collaborative working relationship between quantity surveyors and M\&E consultants engineer leading to a better understanding of M\&E services components by quantity surveyors and more reliable price forecast.

The importance of this study is that, it has specifically identified current practices used for determining and controlling cost of M\&E services and highlighted its impact on the overall procurement and cost of buildings. The potential benefits of adopting a Standard-Based Pricing Mechanism for M\&E services was also ascetained from the perspectives of industry practitioners and strategies to encourage stakeholders to adopt SBPM was sugested. However, the limitations of this study is that, it does not indicate how to develop a Standard Method of Measurement to serve as basis for adopting SBPM for M\&E services price forecast. Therefore, future studies should focus on investigating the essential features of SMM for M\&E services and come up with framework to develop and encourage stakeholders to adopt it as basis for preparing M\&En services price forecast.

\section{Conclusion}

The adoption of SBPM for M\&E services has the potentials of enhancing the procurement and cost management of M\&E services, provides home ground advantage for indigenous industry practitioners and creates a transparent contractual atmosphere for the participation of international contracting organizations and interest groups at the liberalisation of the services sector in the country. Practitioners perceived that the use of SBPM will increase the time required to prepare tender documents as designs will have to be reasonably completed before detail measurements could be undertaken. Contractors are of the opinion that they have a better method of estimating the tender price of M\&E services as the documents prepared by consultants are often inadequate for pricing items of M\&E services. Nevertheless, a systematic structure of Standard-Based BoQ items would lead to a more uniform and adequate descriptions in tender documents, leading to a more reliable M\&E services tender that could be used as basis for historic cost information and provide better value for clients money.

\section{References}

Amaratunga, D., Baldry, D., Sarshar, M. and Newton, R. (2002) Quantitative and Qualitative Research in the Built Environment: Application of "mixed" Research Approach. Work Study, 51 (1), pp. 17-31.

Amuda Yusuf, G., Mohamed, S. F. and Remeli, S. (2013) Factors Inhibiting the Adoption of a Uniform Pricing Mechanism for Building Services. International Journal of Engineering Business Management, 5 (3), pp. 1-10.

Ashworth, A. \& Hogg, K. (2007) Willis's Practice and Procedure for the Quantity Surveyor. 12 éd. Oxford: Blackwell.

Amuda Yusuf, G and Mohamed, S F (2014) 'Perceived benefits of adopting standard - Based pricing mechanism for mechanical and electrical services installations', Australasian Journal of Construction Economics and Building, 14 (2) 104- 
Awakul, P. \& Ogunlana, S. (2002) The Effect of Attitudinal Differences on Interface Conflicts in Large Scale Construction Projects: a Case Study. 20 (4), pp. 365 - $377 .$.

Bowen, P. A. \& Edwards, P. J. (1996) Interpersonal Communication in Cost Planning During the Building Design Phase. Construction Management and Economics, pp. 395 - 404.

CIDB (2009) Annual Report: Strategic Thrust 2 - Strethen the Construction Industry Image, Kuala Lumpur: Construction Industry Development Board.

Davis Langdon (2010) Building Services - Company Profile 2010. [En ligne] Available http://www.davislangdon.com/upload/DLA\%20Brochures/Building\%20Services\%20-

\%20Company\%20Profile\%202010.pdf

[Accès le 18th August 2011].

De Silva, N., Dulaimi, M., Ling, F. \& Ofori, G. (2004) Improving the Maintainability of Buildings in Singapore. Building and Environment, Volume 39, pp. $1243-1251$.

Dell'Isola, M. (2002) Architect's Essentials of Cost Management. New York: John Wiley \& Sons.

Dent, C. (1980) Construction Measurement in Accordance with SMM6: Volume 1 Elementary Substructure and Superstructures. Second Edition éd. London: Granada.

Dulaimi, M. \& Hwa, T. (2003) Developing World Class Construction Companies in Singapore. Construction Management and Economics, Volume 19, pp. 591 - 599.

Dulami, M., Ling, F. \& Bajracharya, A. (2003) Dulami, M.F., Ling, F.Y.Organisational motivation and interorganisational interaction in construction innovation in Singapore. Construction Management and Economics, Volume 21, pp. 307 - 318.

Entrusty (2011) Construction Contract and Management Issues: Ground Conditions - Mysteries Unravelled. Master Builder Journal, Volume 3, pp. 72 - 82.

Fellows, R. \& Liu, A. (2008) Research Methods for Construction. 3rd éd. Chichester: Wiley Blackwell.

Flanagan, R. \& Tate, B. (1997) Cost Control in Building Design. Oxford: Blackwell Science.

Fortune, C. \& Cox, O. (2005). Current practices in building project contract price forecasting in the UK. Engineering, Construction and Architectural Management, 12 (5), pp. 446 - 457.

Fortune, C. \& Lees, M., (1999) The Relative Perfomance of New and Traditional Cost Models in Strategic Advice. Dans: M. Skitmore \& V. Marston, éds. Cost Modeling. London: E \& FN Spon, pp. 93-153.

Fussell, W. (1971) The Measurement of Engineering Services.. London: E\&F.N. Spon Ltd..

Gravetter, F. \& Wallnau, L. (2007) Statistics for the Behavioral Sciences. Seventh Edition éd. Belmont: Thomson Wadsworth.

Gura, J. (1984) Role of the Building Services Engineering Consultants. IEEE Proceedings, 131(6).

Hacket, M., Robinson, L. \& Statham, G. (2007) The Aqua Group Guide to Procurement, Tendering and Contract Administration. Oxford: Blackwell.

Hore, V., Kehoe, J., Macmullan., R. \& Penton, M. (1997) Construction 1: Management, Finance, Measurement for Construction and Built Environment Programmes. Hong Kong: Macmillan.

Ling, Y. \& Boo, J. (2001) Improving the Accuracy of Approximate Estimates of Building Projects,. Improving the Accuracy of Approximate Estimates of Building Projects, Building Research and Information, pp. 312 - 318.

Amuda Yusuf, G and Mohamed, S F (2014) 'Perceived benefits of adopting standard - Based pricing mechanism for mechanical and electrical services installations', Australasian Journal of Construction Economics and Building, 14 (2) 104119 
Mathew, O. \& Howell, G. (2005) Integrated Project Delivery: An Example of Relational Contracting. Lean Construction Journal, 2 (1), pp. 46 - 61.

McCaffrey, J. (2011) What is an M\&E QS. Royal Institution of Chattered Surveyors Students Construction Journal, pp. 22 - 23.

Michie, A. (1981) Integration and Co- ordination of Building Services and its Relationship with Project Management. Building Services Engineering Research and Technology, 2 (15 - 26).

Mok, C., Tummala, V. \& Leung, H. (1997) Practices, barriers and benefits of risk management process in building services cost estimating. Construction Management and Economics, pp. 161 -175 .

Molloy, J. (2007) Civil Engineering Measurement Claims in Hong Kong,. [En ligne] Available at: http://www.fig.net/pub/fig2007/papers/ts 3g/ts03g 02 molloy 1664.pdf [Accès le 28 August 2011].

Murray, G. ( 1997) Measurement of Building Services. London: Macmillan.

Nanayakkahara, R. \& Fitzsimmons, J. (1999) Cost Benchmarks for the Installation of Building Services: Part1 - The Benchmarking Process AG 20 -1/99. BSRIA., London: BSRIA.

Nani, G. E. \& Adjei-Kumi, J. (2008) Customisation and Desirable Characteristics of Standard Method for Building Works in Ghana. Australia Journal of Construction Economic and Building, Vol 8, no 2.

Odeyinka, H., Kelly, S. \& Perera, S. (2009) An evaluation of the budgetary reliability of bills of quantities in building procurement. Cape Town, University of Capetown, pp. 435-446.

Oforeh, E. (2008) Installation and Electrical Works in Buildings. Second Edition éd. Lagos: Cosines.

Oforeh, E. \& Alufohai, A. (1998) Management Estimating and Budgeting for Electricasl Installations. First Edition éd. Lagos: Cosines (Nig) Ltd.

Olatunji, O., Sher, W., Gu, N. \& Ogunsemi, D. (2010) Building Information Modelling Processes: Benefits for Construction Industry. Salford, CIB, pp. 137 - 151.

Potts, K. (2004) Quantity Surveying Tools and Techniques - A Review of Client And Contractor Requirements. Leeds Metropolitant University, RICS Research Foundation.

Potts, K. (2008) Construction Cost Management: Learning from Case Studies. London: Taylor and Francis.

Proverbs, D., Holt, G. \& Olomolaiye, P. (1999) Factor Influencing the Choice of Concrete Supply Methods. Building Research and Information, 25 (3), pp. 176-184.

Rawlinson, S. \& Dedman, A. (2010) Specialist Costs: M\&E Services. Davis Langdon Building Magazine. 2010; available at http://www.davislangdon.com/. [En ligne] Available at: /EME/Research/ResearchFinder/Specialist-Costs/Specialist-Costs---ME-services2010/; [Accès le 25 August 2011].

Rawlison, S., Nugent, B. \& Dedman, A. (2007) Procurement of Building Services. [En ligne] Available at: http://www.davislangdon.com/Global/Search/?q=building+services+procurement

RICS (2000) RICS Guidance Note: Building Services Procurement. London: RICS.

Seeley, I. (1989) Advanced Building Measurement. 2nd éd. London: Macmillan.

Seeley, I. (1996) Building Economics:Appraisal and Control of Building Design Cost and Efficiency. 4th éd. England: MacMillan.

Amuda Yusuf, G and Mohamed, S F (2014) 'Perceived benefits of adopting standard - Based pricing mechanism for mechanical and electrical services installations', Australasian Journal of Construction Economics and Building, 14 (2) 104- 
Seeley, I. \& Winfield, R. (1998) Building Quantities Explained. London: MacMillan.

Skitmore, M. (1991) Which Estimating Technique?. Dans: P. Venmore-Rowland, P. Brandon \& T. Mole, éds. Proceedings of the First National RICS Research Conference. London: Taylor \&Francis.

Skitmore, R. \& Thomas Ng, S. (2003) Forecast Models for Actual Construction Times and Cost. Building and Environment, Volume 38, pp. 1075 - 1083.

Swaffield, L. \& Pasquire, C. (1996) A Crtique of Mechanica and Electrical Services Cost Planning: Existing Methods and Published Information.. Financial Management of Property and Construction, 1 (3), pp. 23 - 41.

Swaffield, L. \& Pasquire, C. (1999) Examination of Relationships Between Building Forms and Function and the cost of Mechanical and Electrical Services.. Construction Management and Economics, Volume 17, pp. 483 - 492.

Swaffield, L. \& Pasquire, C. (2000) Improving Early Cost Advice for Mechanical and Electrical Services RICS Foundation Research Papers; 3 No.15, London: RICS. 